\title{
IMPLEMENTASI COACHING INDIVIDUAL UNTUK PENINGKATAN KOMPETENSI PROFESIONAL GURU PENDIDIKAN AGAMA ISLAM DALAM MELAKSANAKAN PENELITIAN TINDAKAN KELAS
}

\author{
MARDIYATUN \\ Kementerian Agama Kabupaten Kulon Progo DIY \\ Email : Mardiyatun.sumirann@gmail.com
}

\begin{abstract}
ABSTRAK
Penelitian ini bertujuan untuk menguji tingkat efektifitas supervisi akademik melalui Teknik Coaching individual guna meningkatkan kompetensi guru dalam melaksanakan penelitian tindakan kelas. Jenis penelitian deskriptif kualitatif. Subjek utama 16 Guru Pendidikan Agama Islam di Kabupaten Kulon Progo. Aksi yang dilakukan melalui 4 tahapan, yakni perencanaan (planning), pelaksanaan (action), pengamatan (observation), dan perenungan (reflection). Tahapan action dan observation dilaksanakan secara bersamaan. Penelitian ini berlangsung dalam dua (2) siklus sampai terjadi peningkatan atau tercapainya solusi permasalahan yang diangkat. Metode yang digunakan adalah wawancara, kuesioner, dan observasi. Analisis dilakukan melalui tes pemahaman dan hasil produk unjuk kerja. Hasil penelitian menunjukkan bahwa Coaching individual mampu meningkatkan kompetensi guru dalam melaksanakan PTK. Hal ini dibuktikan (1) hasil observasi dan angket menunjukkan tingkat partisipasi meningkat dan peserta merasakan senang mengikuti coaching sebesar $100 \%$ (2) pemahaman konsep tentang PTK meningkat dari sangat rendah menjadi $81.25 \%$ Sangat baik. Hasil penilaian produk PTK di siklus I masih rendah setelah tindakan di siklus II naik secara signifikan menjadi sangat baik (93,75\%), artinya 16 subjek GPAI mampu melaksanakan PTK dengan hasil yang maksimal (4) teknik coaching individual dapat dilaksanakan dengan mudah dan efektif. Kelemahan-kelemahan yang masih terjadi mampu diatasi pada coaching berikutnya.

Kata Kunci: Coaching Individual, Kompetensi Guru, Penelitian Tindakan Kelas
\end{abstract}

\section{PENDAHULUAN}

Sampai saat ini profesi guru masih sangat diminati oleh masyarakat, apalagi setelah adanya kebijakan pemerintah tentang sertifikasi yang memberikan tunjangan jabatan sebesar satu kali gaji dan tunjangn-tunjangan lain yang cukup menggiurkan. Sebagai konsekuensinya pemerintah menuntut agar guru mempunyai empat kompetensi sebagaimana amanat standar nasional pendidikan (2005) bahwa guru harus memiliki kompetensi kepribadian, pedagogik, profesional dan sosial. Keempat kompetensi tersebut merupakan satu kesatuan yang tidak dapat dipisahkan sehingga guru adalah pendidik profesional yang dengan tugas utama mendidik, mengajar, membimbing, mengarahkan, melatih, memberi teladan, menilai dan mengevaluasi peserta didik

Menurut Mulyasa (2007), bahwa peningkatan mutu pendidikan ditunjang oleh guru profesional yang bermutu yang dapat memerankan tugas dan fungsinya dengan baik dalam rangka mempersiapkan sumber daya manusia yang berkualitas melalui proses pembelajaran yang berkualitas pula. Selanjutnya Sagala (2006) mengemukakan sepuluh kompetensi dasar yang harus dimiliki guru, yaitu: (1) menguasai landasan-landasan pendidikan; (2) menguasai bahan pelajaran; (3) kemampuan mengelola program belajar mengajar; (4) kemampuan mengelola kelas; (5) kemampuan mengelola interaksi belajar mengajar; (6) menilai hasil belajar peserta didik; (7) kemampuan mengenal dan menerjemahkan kurikulum; (8) mengenal fungsi dan program bimbingan dan penyuluhan; (9) memahami prinsip-prinsip dan hasil pengajaran; (10) mengenal dan menyelenggarakan administrasi pendidikan, yang harus diimplemntasikan dalam pembelajarannya.

Dengan demikian peningkatan mutu pendidikan hanya dapat dicapai jika guru-gurunya berkompeten dan profesional dalam menjalankan tugasnya. Segala upaya telah dilakukan oleh pemerintah maupun masyarakat dalam meningkatkan kompetensi, profesionalisme serta 


\section{STRATEGY : Jurnal Inovasi Strategi dan Model Pembelajaran Vol 1. No 1. Juli Tahun 2021 e-ISSN : 2798-5466 P-ISSN : 2798-5725}

kesejahteraan guru. Salah satu upaya peningkatan hasil belajar melalui Penilaian Kinerja Guru (PKG) dan Pengembangangan Keprofesionan Berkelanjutan (PKB) guru. Program Penilaian Kinerja Guru (PKG) dan Program Pengembangan Keprofesian Berkelanjutan (PKB) bagi guru.(Permenpan RB nomor 16 tahun 2009). Melalui program PKG dan PKB tersebut diharapkan guru semakin profesional dalam menjalankan tugas dan fungsinya sehingga pada akhirnya diharapkan dapat meningkatkan hasil belajar siswa dan mutu pendidikan secara keseluruhan.

Guru profesional dituntut mampu memecahkan masalah yang terjadi dalam tugas pokok dan fungsi guru itu sendiri dengan tindakan nyata yaitu penelitian tindakan kelas. Dengan melaksanakan tindakan kelas ini apa yang dialami dan dirasakan dalam kelasnya kemudian dipetakan, dianalisis lalu diadakan tindakan solusi secara tepat niscaya dampak langsung terhadap peningkatan pembelajaran akan terlihat nyata.

Tujuan guru melaksanakan Penelitian tindakan kelas antara lain: (1) Meningkatkan mutu proses pembelajaranan di sekolah; (2) Membantu guru mengatasi masalah pembelajaran dan pendidikan di dalam dan luar kelas; (3) Meningkatkan sikap profesional penndidik;(4) Menumbuh-kembangkan budaya akademik dan budaya mutu di lingkungan sekolah sehingga tercipta sikap proaktif di dalam melakukan perbaikan mutu pendidikan dan pembelajaran secara berkelanjutan. Sehingga output atau hasil yang diharapkan melalui Penelitian tindakan kelas adalah terjadinya peningkatan atau perbaikan kualitas proses dan hasil pembelajaran (Dirjend PMPTK, 2010).

Berdasarkan pada hasil pengamatan dan wawancara dan supervisi dilapangan ternyata masih banyak guru agama Islam yang belum pernah melaksanakan kegiatan PKB publikasi ilmiah melaksanakan penelitian tindakan kelas sampai membuat laporan penelitian. Banyak guru yang merasa tidak mampu melaksanakan Penelitian Tindakan Kelas (PTK). Masih rendahnya pemahaman dan keterampilan guru dalam melaksanakan PTK tentunya sangat memprihatinkan. Karena ketidakmampuan guru tersebut dalam melaksanakan penelitian dan membuat laporan penelitian akan berimplikasi pada terhambatnya karier para guru tersebut. Karena salah satu persyarakatan kenaikan pangkat dan jabatan para guru harus mengumpulkan nilai PKB salah satunya adalah PKB Publikasi Ilmiah membuat laporan hasil penelitian.

Melihat kenyataan tersebut penulis merasa prihatin, bagaimana caranya untuk bisa membantu, membebaskan guru dari permasahan tersebut. Sebagai salah satu solusi yang dianggap tepat penulis mengambil tindakan dengan coaching secara individual. Karena melalui teknik coaching guru dapat mengembangkan keterampilan, pengetahuan serta kepribadian secara utuh, sehingga kinerja mereka akan membaik, dan mengarah pada pencapaian tujuan

Teknik coaching dalam penelitian sudah dilakukan sebelumnya oleh beberapa kalangan baik pendidikan, kesehatan, sosial maupun budaya banyak yang menyatakan efektif dalam hasilnya. Demikian juga pada bidang pendidikan menunjukan banyak sekali manfaat kepada guru dan kemudian memberikan banyak sekali dampak yang positif bagi anak dan proses belajar dan mengajar secara keseluruhan. Menurut Nur Muhammad (2018) coaching sangat diperlukan terhadap guru yang mempunyai permasalahan performa kurang dalam hal ketrampilan dan pengetahuan mengenai tugas yang dilakukan serta juga bermanfaat untuk meningkatkan performanya ke level yang lebih tinggi. Dengan menerapkan pendekatan coaching akan efektif dan efisien, dan masih banyak studi menunjukkan manfaat keberhasilan coaching, contohnya saja International Coach Federation (ICF) Melalui proses coaching, 65\% profesional mengalami peningkatan performansi kerja dan $80 \%$ mengaku semakin percaya diri.

Dilansir dari Forbes, Dr. Sally Bonneywell juga memaparkan hasil risetnya di International Journal of Evidence Based Coaching and Coaching, ternyata coaching terbukti membawa transformasi positif kepada kehidupan personal dan profesional Seseorang melalui peningkatan kesadaran diri, kepercayaan diri, dan kepemimpinan diri sehingga mendorong pencapaian tujuan, serta berdampak pada kualitas relasi seseorang dengan keluarga, tim dan orang-orang di sekitarnya. 


\section{STRATEGY : Jurnal Inovasi Strategi dan Model Pembelajaran Vol 1. No 1. Juli Tahun 2021 e-ISSN : 2798-5466 P-ISSN : 2798-5725}

Pengertian teknik coaching sendiri dari segi bahasa menurut Dewan Bahasa dan Pustaka (2013) ialah tunjuk ajar, latih. Sedangkan dari segi istilah, coaching bermaksud membantu seseorang mengeluarkan potensi dirinya bagi memajukan diri dan membuat anjakan yang postitif dalam pemikiran dan tindakan. Dilaksanakan dalam jangka waktu dan untuk keadaan tertentu seperti membangunkan kompetensi tertentu, menumpukan kepada kemajuan prestasi dan pengetahuan.

Ada beberapa pengertian mengenai coaching yang ditemukan para sarjana dan atau praktisi, misalnya O'Connor dan Lages dalam Kaswan (2012) dengan mengutip para pakar, mengemukakan pengertian coaching sebgai berikut:

1) Coaching adalah perubahan kognitif, emosi dan perilaku yang memfasilitasi pencapaian sasaran dan peningkatan kinerja seseorang atau kehidupan pribadi

2) Coaching adalah seni memfasilitasi kinerja, pembelajaran, dan perkembangan orang lain

3) Coaching adalah membekali orang dengan peralatan, pengetahuan, dan kesempatan yang mereka perlukan untuk mengembangkan dirinya dan untuk menjadi lebih efektif

4) Coaching adalah membantu seseorang dengan cara yang dikehendakinya dan menuju arah yang hendak dicapainya. Coaching mendukung seseorang pada setiap level untuk menjadi apa yang mereka inginkan dan menjadi yang terbaik yang mereka mampu

Dengan demikin Coaching adalah sebuah sarana (means) untuk mencapai tujuan, membantu (help) orang-orang menjalankan kehidupan yang utuh dan memuaskan. Adapun prinsip-prinsipnya sebagai berikut: (a) Coaching dipahami sebagai sebuah kendaraan yang penuh tenaga (powerful vehicle) untuk menaikkan kinerja, mencapai hasil-hasil (results) dan mengoptimalkan (optimize) efektivitas pribadi seseorang (b) terfokus demi kemajuan akan penemuan (discovery) .(c) didefinisikan sebagai kemitraan (partnership) dengan klien-klien, dalam sebuah proses pembangkitan pemikiran dan kreativitas berpikir, yang mengilhami untuk memaksimalkan (maximize) potensi pribadi dan profesionalisme mereka.(d) upaya membantu (help) seseorang berubah sejalan dengan yang dia rindukan, menolong (help) dia berjalan ke arah yang diingininya.(e) adanya percakapan (conversation) yang disengaja, secara berkesinambungan, untuk memberdayakan (empower) seseorang atau kelompok, supaya mereka sepenuhnya menjalankan panggilan Allah (God's calling).

Dapat disimpulkan bahwa: 1) metode coaching efektif dalam mengembangkan keterampilan menyapa; 2) untuk keterampilan bercakap-cakap dan bermain informal, metode coaching terbukti cukup efektif sampai tataran kognitif, namun belum dalam bentuk perilaku; 3) diperkirakan terjadi perubahan persepsi yang lebih positif dalam diri subjek ketika menghadapi interaksi sosial. Dengan tahapan-tahapan (a) Goal: menentukan tujuan (b) Reality: menganalisa situasi/keadaan yang ada (c) Options: menimbang- nimbang opsi apa yang dapat dilakukan (d) Will: penentuan reancana (e) Monitoring: mengawasi perkembangan pembelajaran (f) Evaluation: mereview pembelajaran dan kinerja guru

\section{METODE PENELITIAN}

Penelitian ini di setting sebagai penelitian tindakan pengawasan dengan jenis tindakan coaching individual dengan menghabiskan waktu selama 3 bulan dimulai dari Juli sampai akhir bulan September semester 1 Tahun Pelajaran 2018/2019. Penelitian ini dilakukan di wilayah binaan Kantor kementerian Agama Kanupaten Kulon Progo. Adapun Subjek Penelitian adalah Guru Pendidikan Agama dan Islam sebagai guru sebanyak 16 orang yang telah mendaftar dan mengisi angket serta bersedia, sabar dalam mengikuti kegiatan. Yang bertindak sebagai coach adalah penulis sendiri dengan dibantu oleh kolaboran dari LPMP seta mengambil nara sumber lainya untuk menambah penguatan terhadap peserta.

Adapun obyek yang diteliti adalah kemampuan guru dalam melaksanakan penelitian tindakan kelas, dengan dampak dan tujuan yang diharapkan adalah setelah diadakan tindakan coaching secara individual akan terjadi peningkatan kemampuan Guru Agama Islam dalam menyusun penelitian tindakan kelas.Adapun terkait teknik dan instrumen yang digunakan 
adalah (1) data tanggapan peserta terhadap pelaksanaan bimbingan penyusunan PTK digunakan dengan angket instrumennya mengisi pedoman angket (2) data tentang keikutsertaan dilakukan dengan teknik observasi, dan instrumennya berupa lembar observasi checklist. (3) data tentang kemampuan guru dalam melaksanakan penyusunan PTK digunakan intrumen penilaian produk yang dihasilkan berupa laporan dan hasil karya (4) teknik pembahasan dan analisis data menggunakan teknik analisis deskripsi kualitatif serta dibahas sesuai ketentuan dan teori yang ada.

Sedangkan indikator keberhasilan tindakan yang digunakan adalah (1) Supervisi akademik teknik coaching individual telah berjalan sesuai rencana dan sknario yang telah dibuat (2) $\geq 75 \%$ pemahaman terhadap konsep proposal PTK tercapai dengan baik atau sangat baik (3) $\geq 75 \%$ dapat membuat produk dan karya yang berupa proposal dan Penelitian Tindakan Kelas dengan Kategori baik dan atau sangat baik.

\section{HASIL DAN PEMBAHASAN}

\section{Hasil}

Deskripsi data hasil siklus I dilaksanakan selama kurun waktu dua bulan yaitu bulan Juli 2018 sampai Agustus 2018. Sedangkan Siklus II bulan Agustus 2018 sampai September 2018 masing-masig dengan 4 (empat) kali pertemuan dan 4 (empat) tahapan kegiatan, yaitu perencanan, pelaksanaan, observasi dan refleksi.

Dalam rencana tindakan yang dilakukan meliputi: (1) Mentukan fokus masalah yang dihadapi oleh para guru atau peserta, yang akan diperbaiki dan dicrikan solusinya (2) melaksanakan koordinasi dengan peserta terkait teknis yang akan dilakukan dalam pelaksanaan terutama yang berhubungan dengan waktu dan tempat (3) membuat jadwal pelaksanaan tindakan (4). membuat materi supervisi akademik teknik coaching tentang menyusun penelitian tindakan kelas (5). membuat skenario tindakan (6). menyusun instrument proses pelaksanaan penelitian tindakan kelas (7) mempersiapkan instrument evaluasi pemahaman dan instrument tes produk karya, serta lembar pengamatan (8) membuat pedoman pengolahan dan analisis data hasil pengamatan dan tes pemahaman konsep menyusun proposal penelitian tindakan kelas. Langkah berikutnya pelaksanaan tindakan dengan memanfaatkan observasi dengan hasil sebagai berikut:

Tabel 1. Hasil tindakan coaching dari siklus I

\begin{tabular}{|c|c|c|c|c|c|c|c|c|c|c|}
\hline \multirow[b]{3}{*}{$\mathrm{NO}$} & \multirow[b]{3}{*}{ HASIL } & \multicolumn{8}{|c|}{ SIKLUS I } & \multirow[b]{3}{*}{ JUMLAH } \\
\hline & & \multicolumn{8}{|c|}{ SKOR/PREDIKAT } & \\
\hline & & 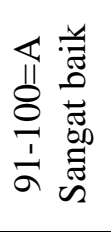 & $b^{\circ}$ & $\begin{array}{l}\frac{y}{7} \\
\oplus \\
0 \\
0 \\
0 \\
\frac{1}{\infty}\end{array}$ & $\Delta$ & 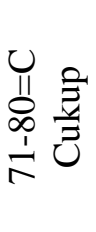 & be & 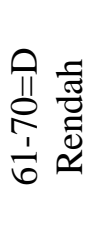 & $b^{\circ}$ & \\
\hline 1 & $\begin{array}{l}\text { Tanggapan } \\
\text { peserta dan } \\
\text { tingkat } \\
\text { partisipasi }\end{array}$ & 16 & 100 & 0 & 0 & 0 & 0 & 0 & 0 & 16 \\
\hline 2 & $\begin{array}{l}\text { Tingkat } \\
\text { pemahaman } \\
\text { konsep PTK }\end{array}$ & 0 & 0 & 0 & 0 & 3 & 8.75 & 13 & 81.25 & 16 \\
\hline 3 & $\begin{array}{l}\text { Tingkat Hasil } \\
\text { produk PTK }\end{array}$ & 0 & 0 & 0 & 0 & 5 & 31.25 & 11 & 86.75 & 16 \\
\hline
\end{tabular}


Tabel.2. Hasil tindakan coaching dari siklus II

\begin{tabular}{|c|c|c|c|c|c|c|c|c|c|}
\hline \multirow[b]{3}{*}{ NO } & \multirow[b]{3}{*}{ Hasil } & \multicolumn{7}{|c|}{ SIKLUS II } & \multirow[b]{3}{*}{ JUMLAH } \\
\hline & & \multicolumn{7}{|c|}{ SKOR/PREDIKAT } & \\
\hline & & 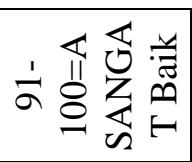 & o & $\begin{array}{l}\infty \\
\substack{11 \\
\frac{1}{\infty}} \\
\frac{\pi}{\pi}\end{array}$ & $\delta^{\circ}$ & 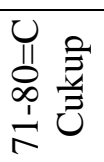 & $b^{\circ}$ & $\begin{array}{l}0 \\
\frac{11}{0} \\
\frac{\pi}{0} \\
\frac{1}{0} \\
0\end{array}$ & \\
\hline 1 & $\begin{array}{l}\text { Tanggapan } \\
\text { peserta dan } \\
\text { tingkat } \\
\text { partisipasi }\end{array}$ & 16 & 100 & 0 & 0 & 0 & 0 & 0 & 16 \\
\hline 2 & $\begin{array}{l}\text { Tingkat } \\
\text { pemahaman } \\
\text { konsep } \\
\text { PTK }\end{array}$ & 13 & 81.25 & 3 & 8.75 & 0 & 0 & 0 & 16 \\
\hline 3 & $\begin{array}{l}\text { Tingkat } \\
\text { Hasil } \\
\text { produk } \\
\text { PTK }\end{array}$ & 15 & 93.8 & 1 & 6.25 & 0 & 0 & 0 & 16 \\
\hline
\end{tabular}

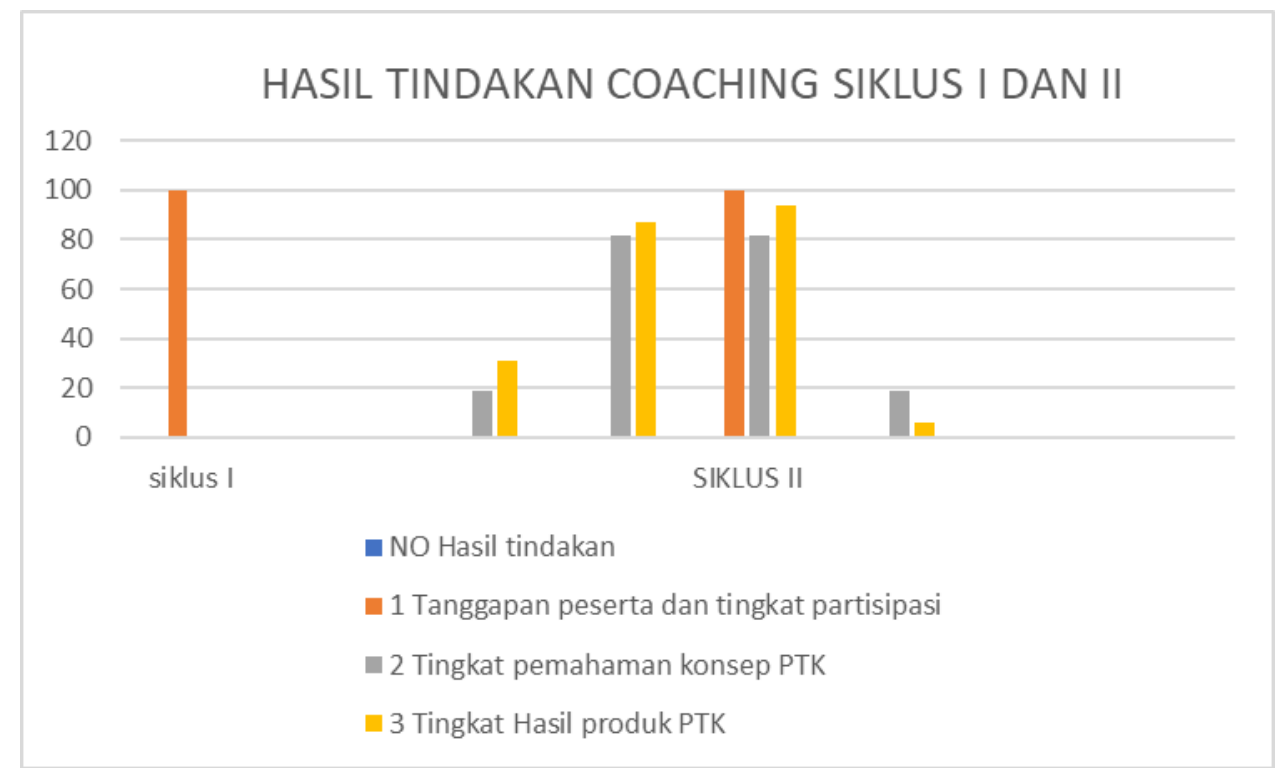

Gambar 1. Grafik Hasil Tindakan Coaching pada diklus I dan II

Hasil refleksi dan evaluasi terhadap hasil tindakan siklus I ternyata masih terjadi kelemahan-kelemahan anatara lain: (1) tingkat keseriuran dan motivasi untuk mengikuti, ketekunan dalam mengerjakan tugas, frekuensi bertanya dan ingin tahu, aktivitas dan kecepatan untuk merespon maupun mempresentasikan hasil karya, serta mampu menerima masukan ternyata masih tergolong rendah (2). Berdasarkan tes hasil pemahaman konsep terlihat belum maksimal terutama dengan latar belakang masalah, rumusan masalah, tujuan penelitian, manfaat penelitian, kegunaan penelitian, kerangka berfikir hipotesis tindakan, metode pengumpulan data, jadwal penelitian dan daftar pustaka (3). Kualitas hasil produks belum sesuai harapan terutama dalam dengan latar belakang masalah, rumusan masalah, tujuan penelitian, manfaat penelitian, kegunaan penelitian, kerangka berfikir hipotesis tindakan, metode pengumpulan data,jadwal penelitian dan daftar pustaka

Untuk mengatasi kelemahan-kelemahan tersebut penulis memutuskan untuk rencana Tindak Lanjut disiklus ke II dengan cara: (1). Diupayakan menciptakan suasana yang menyenangkan dan mengupayakan sarana dan prasarana yang memadai, sehingga guru dalam mengikuti penjelesan tentang kaidah-kaidah penyususnan proposal PTK menjadi utuh dan maksimal (2). Memaksimalkan fungsi bimbingan secara individual serta membangkitkan 


\section{STRATEGY : Jurnal Inovasi Strategi dan Model Pembelajaran Vol 1. No 1. Juli Tahun 2021 e-ISSN : 2798-5466 P-ISSN : 2798-5725}

perasaan ingin tahu lewat diskusi dan Tanya jawab. (3). Mengulang kembali materi-materi yang dirasa sukar, terutama dengan latar belakang masalah, rumusan masalah, tujuan penelitian, manfaat penelitian, kegunaan penelitian, kerangka berfikir hipotesis tindakan, metode pengumpulan data, jadwal penelitian dan daftar pustaka (4). Memberikan contoh-contoh proposal yang telah ditulis oleh pendahulu-pendahulu yang dianggap memenuhi kriteria (5). Mendampingi secara intensip dalam melaksanakan coaching sehingga akan lebih efek. Setelah diadakan perbaikan - perbaikan di siklus ke II sudah mengalami perubahan kearah yang lebih efektif. Hal juga dilihat dari dampak pemahaman peserta terhadap konsep penyususnan proposal PTK dan kemampuan guru dalam menyusun PTK juga sudah seperti yang diharapkan penulis Oleh karena itu penulis memutuskan untuk menghentikan coaching pada siklus ke II.

\section{Pembahasan}

Data dari perkembangan hasil analisis observasi terhadap proses pelaksanaan coaching secara individual pada siklus 1 sampai siklus II secara umum menunjukkan efektifitas yang tinggi karena dapat berjalan dengan baik sesuai dengan rencana yang telah penulis rencanakan dan sesuai indikator keberhasilan tindakan yaitu: Supervisi akademik teknik coaching individual telah berjalan sesuai rencana dan sknario yang telah dibuat (1) $\geq 75 \%$ pemahaman terhadap konsep Penelitian Tindakan Kelas tercapai dengan baik atau sangat baik.(2) $\geq 75 \%$ dapat membuat produk dan karya yang berupa proposal dan Penelitian Tindakan Kelas dengan kategori baik dan atau sangat baik.

Hasil refleksi tentang kekurangan-kekurangan yang terjadi pada siklus 1 yang perlu diperbaiki misalnya pada saat coaching berlangsung ternyata sebagian peserta coaching mengatakan bahwa waktu coaching (pertemuan pendampingan) merasa sangat singkat hanya 2 jam, sementara peserta yang harus dilayani dalam pendampingan secara individual cukup banyak sehingga kesempatan setiap peserta untuk mendapatkan layanan bimbingan dari mentor sangat kurang. Begitu juga saat pendampingan coaching sebagian peserta juga mengatakan bahwa perlu ada bahan ajar yang lengkap, tidak hanya hanya berupa bahan tayang power point. Kekurangan -kekurangan telah diselesaikan hingga sampai siklus II mampu melewati dengan solusi-solusi yang jitu dan tepat.

Melihat hasil analisis tanggapan peserta dan tingkat partisipasi kehadiran tergolong tinggi yaitu $100 \%$ semua peserta hadir dan aktif, mengikuti dengan penuh kesabaran dan konsistesi yang tinggi. Menurut Warso (2014) untuk mengajak agar peserta aktif dan mau membuka diri dalam menghadapi persoalan yang dihadapi maka perlu adanya motivasi baik dalam diri maupun dari luar.

Dari Hasil analisis pemahaman peserta terhadap konsep-konsep penelitian tindakan kelas juga mengalami peningkatan yang sesuai harapan yaitu tingkat ketercapaian $81.25 \%$ dari sebelumya, artinya Guru Pendidikan agama Islam setelah mengikuti coaching dari siklus ke siklus berikutnya telah faham bagaimana membuat proposal yang presentatif dan meneruskan sampai pelaksanaan serta mampu menyususn dalam bentuk laporan, yang akhirnya bermuara pada peningkatan kualitas pendidikan.

Diawal pertemuan pada sampai keberhasilan tercapai perlu adanya motivasi agar peserta semangat karena dalam prakteknya, PTK harus diawali dengan kesadaran untuk berubah. Kesadaran adanya tugas pokok yang harus diemban dan kesadaran akan adanya permasalahan yang dirasakan mengganggu, yang dianggap menghalangi pencapaian tujuan pendidikan sehingga dirasakan telah berdampak kurang baik terhadap proses dan atau hasil belajar pserta didik, dan atau implementasi sesuatu program sekolah. Berawal dari kesadaran mengenai adanya permasalahan tersebut, kemudian guru dibimbing untuk menetapkan fokus permasalahan secara lebih tajam dengan cara memetakan dan menganalisis mengumpulkan tambahan data lapangan secara lebih sistematis dan atau melakukan kajian pustaka yang relevan.

Setelah dibimibing merumuskan maslah kemudian diarahkan untuk dapat melakukan diagnosis kemungkinan-kemungkinan penyebab permasalahan secara lebih cermat, sehingga 


\section{STRATEGY : Jurnal Inovasi Strategi dan Model Pembelajaran Vol 1. No 1. Juli Tahun 2021 e-ISSN : 2798-5466 P-ISSN : 2798-5725}

terbuka peluang untuk memilih alternatif-alternatif tindakan perbaikan yang diperlukan. Alternatif mengatasi permasalahan yang dinilai terbaik, kemudian diterjemahkan menjadi program tindakan perbaikan yang akan dicobakan. Hasil percobaan tindakan perbaikan yang dinilai dan direfleksikan dengan mengacu kepada kreteria-kreteria perbaikan yang dikehendaki, yang telah ditetapkan sebelumnya.

Setelah permasalahan ditetapkan, pelaksanaan PTK dimulai dengan siklus pertama yang terdiri atas empat langkah yaitu perencanaan, pelaksanaan, observasi dan refleksi. Apabila sudah diketahui keberhasilan atau hambatan dalam tindakan yang dilaksanakan pada siklus pertama, peneliti kemudian mengidentifikasi permasalahan baru untuk menentukan rancangan siklus berikutnya. Teknik pada siklus kedua diperlakukan sama dengan sebelumnya agar terjadi konsitensi sehingga hasilnya akan obektif.

Hal ini sejalan dengan Slameto(2015) bahwa untuk memudahkan penyusunan dan menulis hasil PTK lebih dahulu menyusun proposal yang berisi (1) mendeskripsikan dan menemukan masalah (2) menentukan cara pemecahan masalah dengan pendekatan, strategi, media, atau kiat tertentu, (3) memilih dan merumuskan masalah baik berupa pertanyaan atau pernyataan sesuai dengan masalah dan cara pemecahannya, (4) menetapkan tujuan (5) memilih dan menyusun persfektif, konsep, dan perbandingan yang akan mendukung dan melandasi pelaksanaan PTK, (6) merencanakan siklus yang berisi rencana-rencana tindakan (7) menetapkan cara mengumpulkan data sekaligus menyusun instrumen yang diperlukan untuk menjaring data, (8) menetapkan dan menyusun cara-cara analisis data.

Selanjutnya Dwi susilowati (2018) bahwa dalam sikulus itu mengandung empat langkah (1) planning, (2) acting, (3) observing, (4) reflecting, kemudian dijadikan laporan yang berisi (1) setting, (2) hasil per siklus, (3) analisis antar siklus. Hal ini sejalan dengan (Dirjend PMPTK,2010) bahwa Prosedur PTK merupakan proses pengkajian melalui sistem berdaur dari berbagai Teknikpembelajaran. Langkah-langkah pokok yang ditempuh dalam melaksanakan PTK pada siklus pertama dan siklus-siklus berikutnya adalah sebagai berikut; (1) penetapan fokus permasalahan (2) Perencanaan tindakan (3) pelaksanaan tindakan (4) pengumpulan data (5) pengamatan/observasi (6) refleksi (analisis, dan interpretasi) dan (6) Perencanaan tindak lanjut.

Adapun dari hasil analisis produk penelitian tindakan kelas yang dibuat selama mengikuti bimbingan telah menghasilkan sesuai harapan dan indikator keberhasilan. Dalam hal ini ditunjukkan dengan daya serap $93,75 \%$ atau 15 peserta telah berhasil melaksanakan dan menyusun penelitian tindakan kelas dengan sangat baik dan satu peserta mencapai level baik. Dengan demikian pemahaman yang telah dimiliki para peserta dibuktikan dengan hasil produk yang sesuai dengan regulasi yang ada termasuk kerangka penelitian dan langkah-langkahnya.

Sebagaimana Slamet (2015) berpendapat bahwa kerangka penelitian tindakan kelas harus berisi Tiga bagian yaitu (1) bagian awal (halaman sampul, halaman persetujuan, Kata Pengantar dan daftar isi), (2) bagian pokok (Pendahuluan: latar belakang, rumusan masalah dan pemecahannya, tujuan dan manfaat penelitian; Kajian pustaka: kajian teori, kajian hasil penelitian yang relevan, kerangka pikir dan hipotesis, Rencana Penelitian: seting dan subyek penelitian, prosedur PTK, pengumpulan dan analisis data) dan (3) bagian akhit daftar pustaka dan lampiran

Menurut Warso(2014) dalam perumusan permasalahan diperlukan ketelitian dan pilihan kata yang tepat dengan lebih tajam dengan melakukan diagnosis kemungkinan-kemungkinan penyebab permasalahan secara lebih cermat, sehingga terbuka peluang untuk memilih alternatif-alternatif tindakan perbaikan yang diperlukan. Alternatif mengatasi permasalahan yang dinilai terbaik, kemudian diterjemahkan menjadi program tindakan perbaikan yang akan diujicobakan. Hasil percobaan tindakan perbaikan yang dinilai dan direfleksikan dengan mengacu kepada kreteria-kreteria perbaikan yang dikehendaki, yang telah ditetapkan sebelumnya.

Tindakan Coaching yang digunakan dalam penelitian tindakan pengawas untuk meningkatkan kompetensi guru agama Islam merupakan tindakan yang tepat, karena selama ini 


\section{STRATEGY : Jurnal Inovasi Strategi dan Model Pembelajaran Vol 1. No 1. Juli Tahun 2021 e-ISSN : 2798-5466 P-ISSN : 2798-5725}

kejumudan karier dan problematika penilaian kinerja guru yang terjadi selama ini adalah lemahnya guru dalam melaksanakn penelitian tindakan kelas karena tidak ada coaching secara individual. Dengan bimbingan coach secara undividual ini guru merasa terbantu karena Coaching secara konseptual merupakan sebuah kegiatan yang dilakukan untuk membantu meningkatkan kinerja guru dengan melakukan penekanan pada motivator pribadi, memberikan wawasan ke depan, membangun tujuan, menciptakan rencana pengembangan, serta mengenalkan prestasi yang dimiliki oleh guru tersebut Dengan tahapan-tahapan (a) Goal: menentukan tujuan (b) Reality: menganalisa situasi/keadaan yang ada (c) Options: menimbangnimbang opsi apa yang dapat dilakukan (d) Will: penentuan reancana (e) Monitoring: mengawasi perkembangan pembelajaran (f) Evaluation: mereview pembelajaran dan kinerja guru. Dengan langkah-langkah coaching, proses peningkatan motivasi berlangsung alami dan tanpa paksaan karena semuanya muncul dari diri sendiri. Baik solusi bagi permasalahan pekerjaan, ide-ide serta harapan dalam karier semua berasal dari diri sendiri. Dengan mendapatkan proses penguatan dari coach, sehingga timbul motivasi untuk meningkatkan kinerja dari diri sendiri.

\section{KESIMPULAN}

Berdasarkan penelitian yang dilakukan, diperoleh kesimpulan sebagai berikut:

1. Setelah guru mengukiti proses coaching, terdapat beberapa perubahan pada penguasaan konsep penelitian tindakan kelas. Ada tujuh komponen yang telah dikuasai guru dalam memahami konsep penelitian tindakan kelas anata lain: (a) bagian halaman depan yang berisi merumuskan jusdul, halaman pengesahan,halaman dokumentasi,daftar table,daftar lampiran,kata pengantar,daftar isi dan abstrak.(b) bab I pendahuluan:llatarbelakang masalah,rumusan masalah,tujuan peneltian dan manfaat penelitin.(c) bab III kajian pustaka:menjelaskan secara teoritis tentang variable penelitian dengan rujukan yang relevan dari para ahli dana tau hasil penelitian yang senada. (d) bab III: metode penlitian: rancangan penelitian, subyek, waktu dan tempat penelitian, prosedur penelitianteknik pegumpulan data dan analisis data. (e) bab IV hasil penelitian: menyajikan hasil penelitian dan pembahasan hasil penelitrian (f) bab V simpulan dan saran (g) bagian halam belakang: daftar pustaka lampiran data hasil pengamatan dan data lain yang diperlukan terkait tujuan penilaian, foto kegiatan secara kronologis setiap siklus. Daftar hadir surat keterangan penelitian dan semua yang mendukung kegiatan penelitian dan laporan

2. Pelaksanaan Supervisi akademik dengan teknik coaching individual dapat meningkatkan kompetensi guru dalam menyusun penelitian tindakan kelas pada guru-guru PAI binaan dengan peningkatan yang signifikan, yakni ditandai dengan adanya tanggapan peserta yang merasa senang dan aktifitas yang tinggi dengan dibuktikan kehadiran yang maksimal $100 \%$. Partisipasi aktif peserta disetiap diskusi dan kerja kelompok.

3. Kompetensi menyusun penelitian tindakan kelas pada guru pendidikan agama Islam di kabupaten Kulon Progo dapat ditingkatkan melalui supervisi akademik teknik Coaching. Hal ini ditunjukkan dengan daya serap dari pemahaman yang sangat tinggi . Secara klasikal telah terbukti dengan peningkatan sebesar $81,25 \%$ mencapai level yng sangat baik dan $8.75 \%$ di level baik. Demikian juga pada hasil produk PTK buatan Guru yaitu mencapai level yang sangat baik, yaitu $93,75 \%$ atau 15 peserta dan $6.25 \%$ atau 1 peserta pada level baik . Hal ini sesuai dengan tingkat hasil pemahaman yang mereka dapatkan.

4. Supervisi akademik teknik coaching individual dapat dilaksanakan dengan mudah, efektif dan efisien., karena peserta bisa dilayani secara personal sehingga keberhasilan tentu mudah dicapai. Kelemahan-kelemahan yang terjadi sudah bisa diatasi dengan mudah mudah dan tepat. Pemahaman dan hasil kualitas produk guru sebagai peserta coaching bisa digunakan untuk model dan teknik penelitian bernagai bidang, terutama kemajuan pendidikan serta dapat digunakan sebagai acuan dan pedoman dalam melaksanakan Penelitian tindakan kelas selanjutnya. 
DAFTAR PUSTAKA

BSNP. (2007). Peraturan Menteri Pendidikan Nasional Republik Indonesia Nomor 16 Tahun 2007 Tentang Standar Kualifikasi Akademik dan Kompetensi Guru. Jakarta: BSNP.

Depdiknas. (2008). Pedoman Penelitian Tindakan Sekolah (School Action Research) Peningkatan Kompetensi Supervisi Pengawas Sekolah SMA/SMK / SMK. Jakarta: Dirjen PMPTK.

Kemmis, S. and McTaggart, R.1988. The Action Researh Reader.Victoria : Deakin University Press.

Latifah, W. and Muksin, N., 2021. Kontribusi Metode Coaching Dalam Komunikasi Persuasif Pegawai Di Rsud R. Syamsudin, Sh Kota Sukabumi. [online] Jurnal.wicida.ac.id. Available at:

https://jurnal.wicida.ac.id/index.php/sebatik/article/view/1151

[Accessed 15 July 2021].

Mujahidah, Z., 2021.Ptk: Manfaat Bagi Guru, Siswa Dan Sekolah. [online] Zahrotulmujahidah.blogspot.com. Available at: http://zahrotulmujahidah.blogspot.com/2014/12/ptk-manfaat-bagi-guru-siswa-dansekolah.html [Diakses 15 July 2021].

Mulyasa, E (2007) Standar Kompetensi dan sertifikasi Guru Bandung: PT. Remaja Rosdakarya Mulyasa, E. (2002). Manajemen Berbasis Sekolah (Konsep, Strategi, dan Implementasi). Bandung: Remaja Rosdikarya

Noer, M., 2021. Efektivitas Coaching Untuk Mengembangkan Kesuksesan Karyawan | Training Provider Jakarta Indonesia - PT. Presenta Edukreasi Nusantara. [online] Presenta.co.id.

https://jurnal.stie-aas.ac.id/index.php/jie/article/view/175

Peraturan Menteri Agama Republik Indonesia. Nomor 16 Tahun 2010 Tentang Pengelolaan Pendidikan Agama pada Sekolah

Peraturan Menteri Pendidikan dan kebudayaan Republik Indonesia Nomor 62 Tahun 2014 Tentang Standar Proses untuk Satuan Pendidikan Dasar dan Menengah

Peraturan Menteri Pendidikan Nasional Republik Indonesia. Nomor 22 Tahun 2007 Tentang Standar Isi untuk Satuan Pendidikan Dasar dan Menengah.

Peraturan Pemerintah Nomor 19 Tahun 2005 tentang Standar Nasional Pendidikan.

Sagala, H. Syaiful. (2006). Administrasi Pendidikan Kontemporer. Bandung: Alfabeta.

Sudjana, H. Nana. (2009). Penelitian Tindakan Kepengawasan, Konsep dan Aplikasinya bagi Pengawas Sekolah. Jakarta: LPP Binamitra Publishing.

Suhardjono. 2005. Laporan Penelitian Eksperimen dan Penelitian Tindakan Kelas sebagai KTI, Makalah pada "Pelatihan Peningkatan Mutu Guru di Makasar", Jakarta, 2005

Suhardjono. 2005. Penelitian Tindakan Kelas. Makalah pada "Diklat Pengembangan Profesi bagi Jabatan Fungsional Guru", Direktorat Tenaga Kependidikan Dasar dan Menengah, Direktorat Jenderal Pendidikan Dasar dan Menengah, Depdiknas.

Suharsimi Arikunto, Suhardjono, dan Supardi. 2006. Peneilitian Tindakan Kelas. Jakarta: Bina Aksara.

https://media.neliti.com/media/publications/159708-ID-peningkatan-kompetensi-gurumelalui-pene.pdf

https://sinta.unud.ac.id/uploads/wisuda/1112014018-3-2.pdf

https://ejournal.uksw.edu > article > download

Undang-Undang Republik Indonesia Nomor 14 Tahun 2005 tentang Guru dan Dosen.

Undang-Undang Republik Indonesia Nomor 20 Tahun 2003 Tentang Sistem Pendidikan Nasional.

Warso, Agus.2016. Publikasi ilmiah Tinjauan Ilmiah \& Best Practice. Yogyakarta: Pustaka Pelajar 